\title{
The Peculiarities of State Regulation of Innovation Activities of Enterprises in the Global Economy
}

\author{
Yuri A. Kolesnikov' ${ }^{1}$, Tatiana V. Epifanova², Anastasia M. Usenko², Ekaterina Parshina², Victoria N. Ostrovskaya ${ }^{3}$
}

ABSTRACT

\begin{abstract}
The purposes of this article are to determine the peculiarities of state regulation of the innovational activity of enterprises in the global economy, to determine the level of connection between a country's competitiveness in the global economy and the effectiveness of state regulation of innovational activity in that country, and to develop recommendations for improving the process of state regulation of innovational activity of enterprises in the global economy.

To determine the level of connection between a country's competitiveness in the global economy and the effectiveness of state regulation of innovational activity in that country, this study uses the method of correlation analysis, which calculates the coefficient of correlation using mathematical instruments and program methods (MS Excel and MathCad). To evaluate the effectiveness of state regulation of innovational activity of enterprises in the global economy, this study uses a specially developed proprietary methodology.

As a result of this research, the authors determined the following peculiarities of state regulation of innovational activity of enterprises under the conditions of the global economy: an increased role of the innovational sphere in the development of economies, an accelerated rate of development of innovations, activation of the export of innovations, regulation of the entire economy through regulation of the sphere of innovations, and domination by indirect methods of state regulation of innovational activity of enterprises.

For the purpose of improving the process of state regulation of the innovational activity of enterprises under the conditions of the global economy, the authors of this research offer an optimization model.
\end{abstract}

KEY WORDS: $\quad$ state regulation, innovational activity, enterprise, global economy, knowledge economy

JEL Classification: $\quad$ O380, F620

${ }^{1}$ Southern Federal University, Russia; ${ }^{2}$ Rostov State Economic University, Russia; ${ }^{3}$ Moscow Humanitarian and Economic Institute (Stavropol branch), Russia

\section{Introduction}

At present, one of the most important trends in the development of the global economy is the formation -

Correspondence concerning this article should be addressed to: Victoria N. Ostrovskaya, Department of economics and management of Moscow Humanitarian and Economic Institute (Stavropol branch), 330 Mira St., Stavropol, Russia. T: +7-9624-45-25-55. E-mail: ostrovskayav@mail.ru of the knowledge economy. The most economically developed countries are in the final stages of this process. Developing countries are focusing their economic development on accelerated formation of their own knowledge economies. Under these conditions, the competition among countries in the global economy is reaching a new level.

While in the pre-industrial economy competition took place in the agrarian sphere, in the industrial 
economy it took place in the sphere of industrial production, and in the post-industrial economy it takes place in the service sphere, in the knowledge economy - as the highest level of the post-industrial economy competition takes place in the sphere of innovations and scientific research. This requires the development of the sphere of science and education and an increase in the innovational activity of enterprises.

Therefore, issues of state regulation of the innovational activity of enterprises are particularly important in this context. In order to provide the necessary support and stimulation of the innovational activity of enterprises and simultaneously avoid unnecessary expenditures of state budgets, it is essential to determine the peculiarities of state regulation of the innovational activities of enterprises in the modern economy. This is the focus of this article.

On this basis, the authors of this study hypothesize that, in the global economy, the importance of state regulation of innovational activity of enterprises grows, as there is a close connection between a country's competitiveness in the global economy and the effectiveness of state regulation of innovational activity in that country.

The purpose of this article is to verify this hypothesis, which aims to determine the peculiarities of state regulation of innovational activity of enterprises in the global economy, to determine the level of connection between a country's competitiveness in the global economy and the effectiveness of state regulation of innovational activity in that country, and to develop recommendations for improving the process of state regulation of innovational activity of enterprises in the global economy.

\section{Literature review}

The theoretical issues underlying state regulation of economies are examined by numerous current authors, in which they substantiate the necessity of state regulation of economic systems, discuss the level of necessary state interference into the workings of market processes, and determine the top-priority spheres of state regulation. Authors who have addressed these issues include (Adigamova, Safiullin, \& Tufetulov, 2014; Bagautdinova, Malakhov, Vardanyan, \& Shakhnina, 2014; Guerriero, 2013; Veselovsky, Abrashkin, Aleksakhina, \& Pogodina, 2014; Zobova, Zagladina,
Safiullin, \& Malganova, 2014 etc.). Within state regulation of an economy, a policy of freetrading can be implemented, which aims at developing national markets and stimulating free competition (Dzeverina, 2013). A policy of protectionism, aimed at protecting domestic manufacturers from external competition (Ryspekova \& Beissekeyeva, 2013), can also be used. Top-priority spheres of state regulation are the defense industry and agriculture (Suntsova, 2012).

Methodological aspects of state regulation of the economy are related to studies of the most important characteristics of the applied and prospective instruments of state economic policy, the peculiarities of applying these instruments in various spheres of the economy under various economic conditions, and methods for evaluating the effectiveness of state interference into economic processes. These topics are addressed in the works of such researchers as (Gataullin, Askarov, Khuzhakhmetova, \& Yarkov, 2015; Radu, 2012; Ryazantsev, Karabulatova, Ter-Akopov, Pismennaya, \& Bozhenko, 2015; Suntsova, 2013, Tkhakushinov, Zarubin, Nekrasova, Kuizheva, \& Ovsyannikova, 2015). Economic methods of regulation include monetary and financial policy (Lan, Pickles, \& Zhu, 2015). Administrative methods of economic regulation include such measures as prohibition, permission, and enforcement (Lomeiko, 2015). The effectiveness of state regulation of the economy is determined by the ratio of received economic profit to expenditures on regulations.

Many authors have examined the practical aspects of state regulation of economies using the examples of various countries and regions that have successfully used specific tools of state interference in economies. Some authors have also examined the causes of failure of such interference, obstacles on the path to successful state regulation of economic systems, and possibilities for modeling and forecasting the consequences of state interference with market processes. These authors include (Agénor, Alper, \& Pereira da Silva, 2014; Charlot, Malherbet, \& Terra, 2015; Nurunnabi, 2015; Popkova, Yurev, Stepicheva, \& Denisov, 2015; Uberti, Lemay-Hébert, \& Demukaj, 2014; Wang, Zhang, \& Zeng, 2016)

Modern Russia uses a state policy of protectionism, within which the state protects internal markets from foreign enterprises (rivals) in order to protect domestic manufacturers (Duncan, 2014). The USA and countries 10 
of Western Europe use a policy of free trade, within which the maximum effectiveness of market mechanisms is achieved (Warren \& Wood, 2014). The consequences of state interference in economic processes are often modeled, but due to a variety of factors, the forecasts are not always precise (Kim \& Kim, 2014).

Many authors have studied the innovational activity of enterprises under modern economic conditions. These authors have determined the most promising directions of innovational initiatives, the most important factors and conditions supporting the development and implementation of innovations at enterprises in various countries around the world, and the national peculiarities of innovational activity. The works of the following scholars should be recognized: (Allan, Crouchley \& Robertson, 2012; Anatolyevna \& Vladimirivna, 2014; Bayev \& Podshivalova, 2013; Nechaev \& Antipina, 2015; Ryapukhina, Suprun, Doroshenko, Bukhonova, \& Somina, 2015), etc. Innovational activity can improve internal business processes (Imanbekova, 2014) and modify existing ones, or it can lead to the development and manufacture of innovative products (Tovt, 2014). Innovations ensure the development of enterprises and support their competitiveness (Belkin \& Belkina, 2013).

A review of the literature on this topic showed that despite extensive discussion of the issues of state regulation of economies and innovational activity of enterprises, there is a lack of complex research into the peculiarities of state regulation of the innovational activity of enterprises in the global economy. This article seeks to fill this gap.

\section{Method}

To verify the proposed hypothesis and determine the level of connection between a country's competitiveness in the global economy and the effectiveness of state regulation of innovational activity in that country, this study uses the method of correlation analysis, which calculates coefficients of correlation using mathematical instruments and program methods; in this case, the authors chose MS Excel and MathCad.

With the help of this method, the authors determined the dependence of the value of the index of global competitiveness of countries on the level of effectiveness of state regulation of innovational activity of enterprises in the global economy. For the purpose of evaluating the effectiveness of state regulation of the innovational activity of enterprises in the global economy, this study uses a specially developed proprietary methodology:

Ceff=Pinn+Einn $/$ Finn + Rinn

where Ceff - coefficient of effectiveness of state regulation of innovational activity of enterprise in the global economy;

Pinn - volume of innovational products, works, and services, USD million;

Einn - export of innovational technologies, USD million; Finn - state financing of innovational research, USD million;

Rinn - expenditures of business for scientific research and implementation of innovations into production, USD million.

As is seen in formula (1), within this methodology, the coefficient of effectiveness of state regulation of innovational activity of enterprises in the global economy is calculated, which is found as the ratio of the sum of the volume of innovational goods, works, and services and exports of innovational technologies to the ratio of the sum of the volume of state financing of innovational research and expenditures of the business for scientific research and implementation of innovations into production.

\section{Results}

On the basis of statistical information regarding development of the innovational sphere, we build a compiled table that contains information on the dynamics of the values of indicators of effectiveness of state regulation of innovational activity of enterprises in the global economy in the USA, France, and Russia for 2010-2014 (Table 1).

This allows calculating the values of the coefficients of effectiveness of state regulation of innovational activity of enterprises in the global economy in the USA, France, and Russia for 2010-2014 (Table 1). Official statistics of the global competitiveness of the USA, France, and Russia for 2010-2014 are shown in Table 2.

By calculating parameters of the function of paired linear regression for characteristics of the dependence of a country's competitiveness in the global economy (y) 
Table 1. Dynamics of values of indicators of effectiveness of state regulation of innovational activity of enterprises in the global economy in the USA, France, and Russia for 2010-2014

\begin{tabular}{|c|c|c|c|c|}
\hline \multirow{2}{*}{ Year } & \multicolumn{4}{|c|}{ Values of indicators of effectiveness } \\
\hline & Pinn & Einn & Finn & Rinn \\
\hline \multicolumn{5}{|c|}{ USA } \\
\hline 2010 & $2,401,684.40$ & $89,791.00$ & $58,364.00$ & $37,371.87$ \\
\hline 2011 & $3,160,111.05$ & $94,280.55$ & $59,823.10$ & $40,259.78$ \\
\hline 2012 & $4,213,481.40$ & $98,994.58$ & $61,318.68$ & $46,955.90$ \\
\hline 2013 & $5,745,810.40$ & $103,944.31$ & $62,851.64$ & $53,836.14$ \\
\hline 2014 & $7,015,732.00$ & $109,141.52$ & $64,422.94$ & $57,676.74$ \\
\hline \multicolumn{5}{|c|}{ France } \\
\hline 2010 & $849,826.79$ & $8,865.51$ & $20,906.10$ & $34,495.07$ \\
\hline 2011 & $1,118,193.14$ & $10,904.58$ & $22,996.71$ & $37,944.57$ \\
\hline 2012 & $1,490,924.19$ & $13,412.63$ & $25,296.38$ & $41,739.03$ \\
\hline 2013 & $2,033,132.91$ & $16,497.53$ & $27,826.02$ & $45,912.93$ \\
\hline 2014 & $2,482,489.78$ & 20,291.97 & $30,608.62$ & $50,504.22$ \\
\hline \multicolumn{5}{|c|}{ Russia } \\
\hline 2010 & $18,474.50$ & $3,854.57$ & $3,473.26$ & $7,474.37$ \\
\hline 2011 & $24,308.55$ & $5,071.80$ & $3,656.06$ & $8,051.96$ \\
\hline 2012 & $32,411.40$ & $6,420.00$ & $4,829.22$ & $9,391.18$ \\
\hline 2013 & $44,198.54$ & $7,642.86$ & $5,475.69$ & $10,767.23$ \\
\hline 2014 & $53,967.17$ & $8,991.60$ & $6,543.10$ & $11,535.35$ \\
\hline
\end{tabular}

Source: Adapted from "Russia in numbers. Scientific research and innovations 2015: Bulletin of Rosstat" by Rosstat (2015). Retrieved from Retrieved from http://www.gks.ru/free_doc/doc_2015/rusfig/rus-15.pdf

and the effectiveness of state regulation of innovational activity in that country ( $\mathrm{x}$ ) on the basis of statistical data with the help of the program MathCad, we have the following models:

$$
\begin{aligned}
& \mathrm{y}(\mathrm{x})_{\text {USA }}=0.91+0.15 \mathrm{x} . \\
& \mathrm{y}(\mathrm{x})_{\text {France }}=1.39+0.34 \mathrm{x} . \\
& \mathrm{y}(\mathrm{x})_{\text {Russia }}=1.65+2.84 \mathrm{x} .
\end{aligned}
$$

Let us evaluate the quality of the received regression models. Index $b=0.14$ shows that with an increase in the effectiveness of state regulation of the innovational activity of an enterprise by 1 , the competitiveness of the USA grows by 0.15 , of France - by 0.34 , and of Russia - by 2.84. Coefficients of correlation for received models $-r_{x y}=0.97$. It is possible to conclude that there is a close correlation between the viewed indicators. Let us calculate the coefficient of determination: $\mathrm{D}=\mathrm{r}_{\mathrm{xy}}^{2}{ }^{*} 100 \%=97 \%$.

Consequently, the competitiveness of a country in the global economy can be $97 \%$ explained by the effectiveness of state regulation of innovational activity in that country. Let us evaluate the model of linear regression through average error of approxi- 


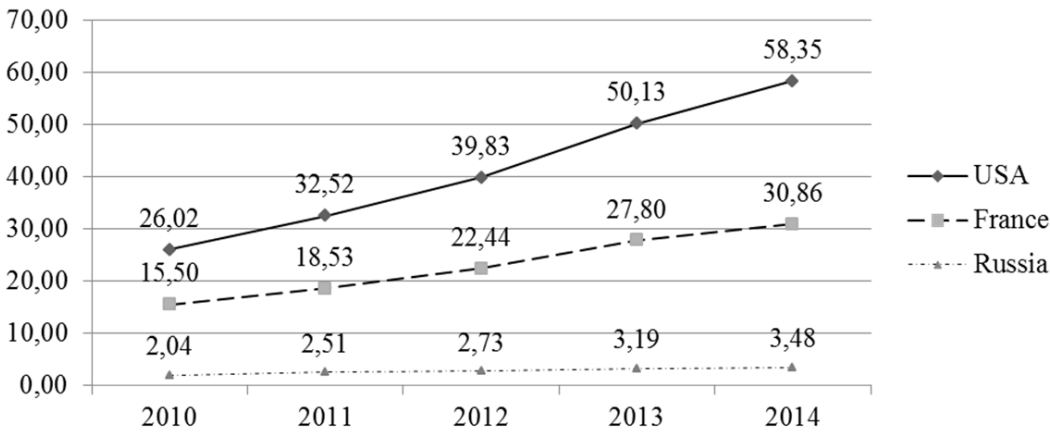

Figure 1. Dynamics of values of the coefficient of effectiveness of state regulation of innovational activity of enterprises in the global economy of the USA, France, and Russia for 2010-2014

Source: Adapted from "Russia in numbers. Scientific research and innovations 2015: Bulletin of Rosstat" by Rosstat (2015). Retrieved from http://www.gks.ru/free_doc/doc_2015/rusfig/rus-15.pdf

Table 2. Statistics of global competitiveness of the USA, France, and Russia for 2010-2014

\begin{tabular}{lcccccc}
\hline & \multicolumn{2}{c}{ USA } & \multicolumn{2}{c}{ France } & \multicolumn{2}{c}{ Russia } \\
\cline { 2 - 7 } Year & $\begin{array}{c}\text { Value of } \\
\text { index }\end{array}$ & $\begin{array}{c}\text { Position in } \\
\text { rankings }\end{array}$ & $\begin{array}{c}\text { Value of } \\
\text { index }\end{array}$ & $\begin{array}{c}\text { Position in } \\
\text { rankings }\end{array}$ & $\begin{array}{c}\text { Value of } \\
\text { index }\end{array}$ & $\begin{array}{c}\text { Position in } \\
\text { rankings }\end{array}$ \\
\hline 2010 & 99.091 & 3 & 74.372 & 28 & 49.318 & 51 \\
2011 & 100.00 & 1 & 71.394 & 29 & 58.376 & 49 \\
2012 & 97.755 & 2 & 70.003 & 29 & 55.159 & 48 \\
2013 & 100.000 & 1 & 71.327 & 28 & 56.809 & 42 \\
2014 & 100.000 & 1 & 67.941 & 27 & 57.997 & 38 \\
\hline
\end{tabular}

Source: Adapted from "IMD world competitiveness yearbook 2014" by IMD (2014). Retrieved from https://www.imd.org/uupload/IMD.WebSite/wcc/WCYResults/1/scoreboard_2014.pdf

mation, which for this model is $3 \%$. This shows that the model is of high quality.

Under the conditions of the global economy, the sense changes and specific peculiarities of innovational activity of enterprises emerge. Innovations from additional competitive advantages and unique features gradually become inseparable attributes of conducting business and necessary conditions for the successful existence of modern enterprises.

With the accumulation of experience in creating and implementing innovations, sustainable public opinion regarding an innovator's responsibility for his inventions is formed. Modern consumers become more and more knowledgeable and selective regarding innova- 
tional products and are interested in the social and ecological responsibility of businesses; they prefer responsible innovations that do no harm but rather produce only profit for the workers who manufacture them and for the surrounding environment and society.

In recent years, both patent law and systems of protection for innovators' interests have been actively developing. This is necessary to support interest in new inventions. At the same time, many innovations are borrowed from multiple rivals after the termination of patents for the purpose of preserving competitiveness, as consumers will not purchase outdated products and will instead choose new goods once innovations are implemented and produced by at least one company in the market.

High-quality transformation of the sphere of innovations predetermines the emergence of certain peculiarities of state regulation of the innovational activity of enterprises in the global economy. First, the innovational activity of enterprises determines national competitiveness, which increases the importance of regulating this type of activity and makes it a top-priority in an economy's development. At present, the attention of governments in developed countries is focused on innovational enterprises, as the entire society is interested in their successful functioning and development.

Second, under the conditions of globalization, there is close cooperation among various economic systems. This ensures favorable conditions for the exchange of accumulated experience and the transfer of knowledge within the general global economic system. Under these conditions, the tendency to export innovations develops, and innovations become the objects of the foreign economic trade relations of various countries.

Here we face a contradiction of interests in countries that export innovations. On the one hand, exporting innovations generates profit, stimulates revenues for the state budget, and contributes to development of the national economy. However, on the other hand, innovations determine the competitive advantages of a country in the global economy, and their export makes innovations generally accessible, which eliminates this advantage.

This contradiction can be partially solved through export not of innovative technologies but rather of innovative goods that are manufactured with the help of these technologies. This allows countries to preserve their competitive advantages and develop exports not of a single technology but of a series of innovative products to various countries around the world.

Third, under the conditions of an innovational economy, new technologies are implemented in all spheres of the economy, so it is possible to regulate the whole economy through regulation of the sphere of innovations. In other words, investments in new technologies positively influence the whole economic system and stimulate its development.

This motivates developing countries to build innovation-oriented economies, which are capable of generating innovations, distributing new knowledge in all spheres of the economy, and ensuring their quick implementation into productive activities of national enterprises.

Fourth, the rate of technology creation is accelerating. While a hundred years ago, the cycle of technological renewal required approximately 30 years, at the beginning of the new millennium, this decreased to 7-10 years, and innovational leaps currently take place each year. This causes a very rapid aging of technologies and equipment and creates a necessity for constant productive modernization.

For this reason, the governments of the most economically developed countries finance investment projects to create new technologies and not to develop manufacturing for innovative products. The efforts of the state are usually directed at realizing long-term research projects, which are prospective but insufficiently attractive for private investors.

Fifth, this study notes the domination of indirect methods of state regulation of the innovational activity of enterprises over methods of direct regulation. This is expressed by a reduction in the state budget in the share of financing for the sphere of science and innovation, the general structure of financing for the innovational activity of enterprises, and the domination of private innovations in this sphere.

This is caused by the increased interest of private investors in the innovational sphere and the goal of saving the assets of the state budget. Moreover, in recent years, under the influence of integration processes and under conditions of global competition, there has been growing interest among enterprises in financing scientific research and implementing innovational technologies into production for the purpose 


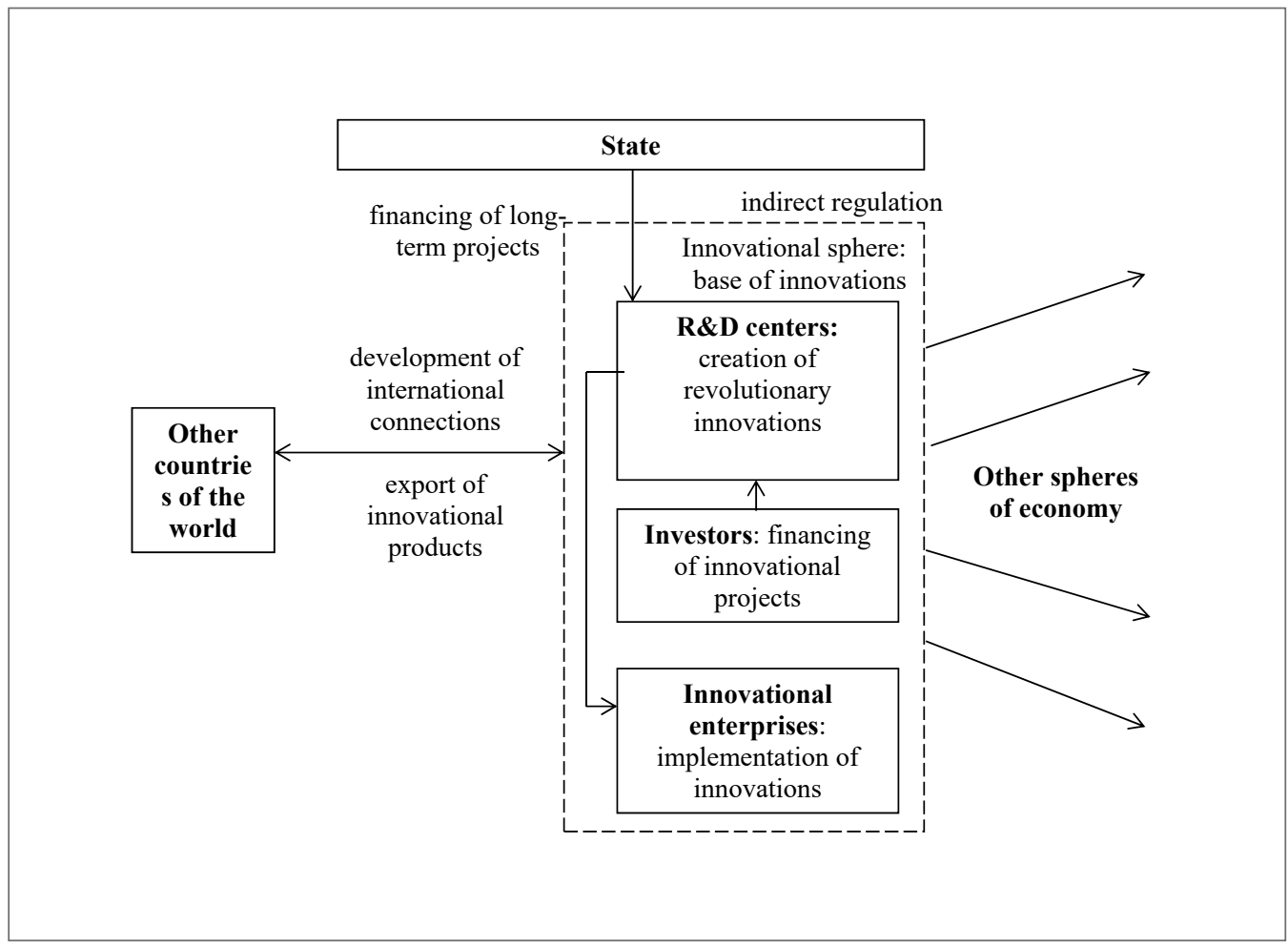

Figure 2. Optimization model of state regulation of innovational activity of enterprises in the global economy

of preserving competitiveness and preserving or increasing market share.

The above features are particular to the global economy as a whole and can be manifested to different extents in various countries, due to national peculiarities and levels of economic development. However, despite differences in the innovational spheres of various countries, they are all interested in their own development. This research offers the following recommendations for improving the process of state regulation of the innovational activity of enterprises in the global economy:

- rejecting the model of overcoming the development of innovations, which supposes the development of evolutionary innovations aimed at improving existing technologies in existing markets and transitioning to the development of revolutionary innovations, which supposes the creation of completely new products and the establishment of new markets;
- formation of the basis of innovation, which should connect innovators, investors, and entrepreneurs. This creates favorable conditions for commercialization of innovations and stimulates their quick integration into productive activities of modern enterprises;

- development of international connections in the sphere of innovations, especially among developing countries. This will allow the exchange of experience and the conduct of joint research to create innovations by means of combining human and financial resources;

- development of institutional bases and infrastructural provisions for the creation and implementation of innovations into production. This is especially important for developing countries, where there are no platforms for the development of innovations; this is a serious barrier to creating innovation-oriented economies in these countries. 
To realize the above recommendations, the authors of this research offer an optimization model of state regulation of the innovational activity of enterprises in the global economy (Fig. 2).

\section{Conclusion}

As a result of correlation analysis, the close connection between the global competitiveness of countries (in terms of the level of effectiveness of state regulation of innovational activity of enterprises in the global economy) was determined using the examples of the USA, France, and Russia. This proves the hypothesis of this article and shows that in the global economy, the need for state regulation of the innovational activity of enterprises is especially high.

It should be noted that the hypothesis of this article is more applicable to developed countries, as they have more capabilities and opportunities for the creation and implementation of innovations. However, to reduce the gap between various countries in the global economy, it is necessary to intensify innovative activities in developing countries. Taking into account their unfavorable institutional conditions and entrepreneurial climates, the key role in increasing the innovative activity of enterprises in developing countries belongs to the state.

This theory could be further developed due to the strengthening of global competition. The innovational economy is the highest form of economic development. That is why, when conducting further research in this sphere, it is expedient to pay special attention to the development of corresponding institutional and infrastructural environments and to the issue of international economic cooperation in the innovational sphere.

An advantage of this methodology for evaluating the effectiveness of state regulation of the innovational activity of enterprises in the global economy is the simplicity and clarity of its calculations, which sets it apart from the multiple indices prepared by various international organizations. As a result of this evaluation, it was determined that the highest effectiveness of state regulation of innovational activity of enterprises is found in the USA, and the lowest - in Russia.

This is caused by national peculiarities, which include different levels of development of innovations and production and differences in other indicators of competitiveness (which are taken into account in the international rankings). It is also caused by differences in general economic effectiveness, which is related to the different qualities of the institutional infrastructure in these economic systems.

The peculiarities of state regulation of the innovational activity of enterprises in the global economy include the growing role of the innovational sphere in the development of economies, the acceleration of the rates at which innovations are developed, the exports of innovations, the regulation of the whole economy through regulation in the sphere of innovations, and the domination of indirect methods of state regulation of the innovational activity of enterprises.

For the purpose of improving the process of state regulation of the innovational activity of enterprises in the global economy, the authors of this study offer an optimization model that supposes a transition to the development of revolutionary innovations; the formation of innovative bases that connect innovators, investors, and businessmen; the development of international connections in the sphere of innovations; the development of institutional bases; and infrastructural provisions for the creation and implementation of innovations into production.

It can be concluded that the results of correlation analysis are limited by the size of selection and the use of only three studied countries. To obtain more precise results and calculate a global coefficient of correlation that reflects the dependence of the global competitiveness of countries on the level of effectiveness of state regulation of the innovational activity of enterprises in the global economy, it is advisable to conduct further research using examples from other countries around the world.

\section{References}

Adigamova F. F., Safiullin M. A., \& Tufetulov A. M. (2014). Mechanism of state tax regulation in the global economy. Mediterranean Journal of Social Sciences, 5(24), 193-199.

Agénor, P. R., Alper, K. \& Pereira da Silva, L. A. (2014). Sudden floods, macroprudential regulation and stability in an open economy. Journal of International Money and Finance, 48, 68-100.

Allan, R., Crouchley, R., \& Robertson A. (2012). Collaborative and distributed innovation and research 
in business activity. In A. A. Juan, T. Daradoumis, M. Roca, S. E. Grasman, \& J. Faulin (Eds.), Collaborative and distributed e-research: Innovations in technologies, strategies and applications, (pp. 310330). United States of America, USA: Information Science Reference IGI Global.

Anatolyevna, M. I., Vladimirivna, P. L. (2014). The use of subcontracting mechanisms in education as means of the increase of business and innovation activity of higher education institutions. World Applied Sciences Journal, 31(5), 884-888.

Bagautdinova, N. G., Malakhov, V. P., Vardanyan, E. A., \& Shakhnina, I. Z. (2014). Implementation of state regulation of small enterprises in the modern economy. Mediterranean Journal of Social Sciences, 5(18), 11-16.

Bayev, I. A., Podshivalova, M. V. (2013). Tasks of institutional support to increase innovation activity of small business in the region. Economy of Region, 2013(1), 189-198.

Belkin, V. N., \& Belkina, N. A. (2013). Ways of increasing enterprises' innovation activity. Economy of Region, 2013(1), 238-242.

Charlot, O., Malherbet, F., \& Terra, C. (2015). Informality in developing economies: Regulation and fiscal policies. Journal of Economic Dynamics and Control, 51, 1-27.

Duncan, J. (2014). A political economy of press selfregulation: The case of South Africa. Media, Culture and Society, 36(2), 167-182.

Dzeverina, K. S. (2013). Формування інституційного механізму регулювання державно $\backslash$ власності в національній економіці України. [Institutional mechanism formation for state property regulation within the national economy of Ukraine]. Actual Problems of Economics, 147(9), 49-56.

Gataullin, R. F., Askarov, A. A., Khuzhakhmetova, G. N., \& Yarkov, N. V. (2015). Organizational and economic forms and effective methods of state regulation of agriculture. Economy of Region, 42(2), 271-284.

Guerriero, C. (2013). The political economy of incentive regulation: Theory and evidence from US states. Journal of Comparative Economics, 41(1), 91-107.

Imanbekova, M. (2014). The use of foreign experience in forming system state regulation of innovation ac- tivities of enterprises in the Republic of Kazakhstan. World Applied Sciences Journal, 30(5), 630-634.

IMD (2014). IMD world competitiveness yearbook 2014. Retrieved from https://www.imd.org/uupload/IMD.WebSite/wcc/WCYResults/1/scoreboard_2014.pdf

Kim, I., \& Kim, I. (2014). Guest editors' introduction: Financial supervision and regulation with emphasis on Korea and emerging market economies. Emerging Markets Finance and Trade, 50(6), 1-4.

Lan, T., Pickles, J., \& Zhu, S. (2015). State regulation, economic reform and worker rights: The contingent effects of China's labour contract law. Journal of Contemporary Asia, 45(2), 266-293.

Lomeiko, Y.A.(2015). Митне регулювання і контроль у контексті розвитку зовнішньоекономічних відносин в Україні. [Customs regulation and control in the context of external economic relations development in Ukraine]. Actual Problems of Economics, 166(4), 75-93.

Nechaev, A., \& Antipina, O. (2015). Tax stimulation of innovation activities enterprises. Mediterranean Journal of Social Sciences, 6(1S2), 42-47.

Nurunnabi, M. (2015). Tensions between politicoinstitutional factors and accounting regulation in a developing economy: Insights from institutional theory. Business Ethics, 24(4), 398-424.

Popkova, E. G., Yurev, V., Stepicheva, O., \& Denisov, N. (2015). Transformation and concentration of intellectual capital as a factor of economic growth in the modern economy. Regional and Sectoral Economic Studies, 15(1), 53-60.

Radu, L. D. (2012). Economic growth through ecoefficient methods and strategies: Regulations and achievements in Romania. Paper presented at Proceedings of the 18th International Business Information Management Association Conference, May 10-12, 2012. Istanbul, Turkey.

Rosstat. (2015). Russia in numbers. Scientific research and innovations 2015: Bulletin of Rosstat. Retrieved from http://www.gks.ru/free_doc/ doc_2015/rusfig/rus-15.pdf

Ryapukhina, V. N., Suprun, E. V., Doroshenko, Y. A., Bukhonova, S. M., Somina, I. V. (2015). Strategy of effective management for small businesses at different stages of innovation activity. Journal of Applied Engineering Science, 13(2), 117-125. 
Ryazantsev, S. V., Karabulatova, I. S., Ter-Akopov, A. A., Pismennaya, E. E., \& Bozhenko, V. V. (2015). The specificity of the differential regulation of economic integration in the context of contemporary labor migration. Mediterranean Journal of Social Sciences, 6(3), 96-102.

Ryspekova, M. O., \& Beissekeyeva, A. K. (2013). Analysis and ways of state regulation of social security system in the Republic of Kazakhstan under economy modernization. Actual Problems of Economics, 148(10), 456-463.

Suntsova, А. О. (2012). Методологічні засади оцінювання ефективності макроекономічного регулювання розвитку національного господарства. [Methodological grounds for efficiency evaluation of state regulation of national economy development]. Actual Problems of Economics, 134(8), 139-145.

Suntsova, А. О. (2013). Фінансові методи в регулюванні економічного розвитку країни. [Financial methods in regulation of economic development of a country]. Actual Problems of Economics, 140(2), 29-33.

Tkhakushinov, E. K., Zarubin, V. I., Nekrasova, S. O., Kuizheva, S. K., \& Ovsyannikova, T. A. (2015). Algorithm for organizing the process of ecological and economic system regulation of the territorial unit. Asian Social Science, 11(14), 297-305

Tovt, T. I. (2014). Regulation mechanism for investment support of innovation activities of enterprises. Actual Problems of Economics, 152(2), 211-218.

Uberti, L. J., Lemay-Hébert, N., \& Demukaj, V. (2014). Introduction: The political economy of regulation in post-war Kosovo: intended and unintended consequences of external actors' involvement. East European Politics, 30(4), 429-435.

Yakovlevich Veselovsky, M., Sergeevich Abrashkin, M., Griegorievna Aleksakhina, V., Vitalievna Pogodina, T. (2014). Features of state regulation of the economy in terms of its transition to innovative way of development. Asian Social Science, 11(1), 288-296.

Wang, Z., Zhang, B., \& Zeng, H. (2016). The effect of environmental regulation on external trade: Empirical evidences from Chinese economy. Journal of Cleaner Production, 144, 55-61.

Warren, P. L., \& Wood, D. H. (2014). The political economy of regulation in markets with naïve con- sumers. Journal of the European Economic Associa- 386 tion, 12(6), 1617-1642. 387

Zobova, I.Y, Zagladina, E. N., Safiullin, L. N., \& Mal- 388 ganova, I. G. (2014). Institutional aspects of state $\quad 389$ regulation in cyclic development of economy con- $\quad 390$ ditions. Mediterranean Journal of Social Sciences, 391 5(28), 40-44. 392 